\title{
Perspectives on the Biogenesis of Iron Oxide Complexes Produced by Leptothrix, an Iron-oxidizing Bacterium and Promising Industrial Applications for their Functions
}

Tatsuki Kunoh ${ }^{1,2}$, Hitoshi Kunoh ${ }^{1,2}$ and Jun Takada ${ }^{1,2 *}$

${ }^{1}$ Core Research for Evolutionary Science and Technology (CREST), Japan Science and Technology Agency (JST), Okayama, Japan

${ }^{2}$ Graduate School of Natural Science and Technology, Okayama University, Okayama, Japan

\begin{abstract}
Leptothrix species, one of the Fe-/Mn-oxidizing bacteria, are ubiquitous in aqueous environments, especially at sites characterized by a circumneutral $\mathrm{pH}$, an oxygen gradient and a source of reduced $\mathrm{Fe}$ and $\mathrm{Mn}$ minerals. Characteristic traits that distinguish the genus Leptothrix from other phylogenetically related species are its filamentous growth and ability to form uniquely shaped microtubular sheaths through the precipitation of copious amounts of oxidized $\mathrm{Fe}$ or $\mathrm{Mn}$. The sheath is an ingenious hybrid of organic and inorganic materials produced through the interaction of bacterial exopolymers with aqueous-phase inorganics. Intriguingly, we discovered that Leptothrix sheaths have a variety of unexpected functions that are suitable for industrial applications such as material for lithium battery electrode, a catalyst enhancer, pottery pigment among others. This review focuses on the structural and chemical properties of the Leptothrix sheaths and their noteworthy functions that show promise for development of cost-effective, eco-friendly industrial applications.
\end{abstract}

Keywords: Leptothrix; Iron-oxidizing bacteria; Microtubular sheath; Iron oxide complex; Organic/inorganic hybrid material; Catalyst enhancer; Li-ion battery anode material; Porcelain pigment

\section{Introduction}

Biomineralization, defined as the study of the formation, structure and properties of inorganic solids deposited in biological systems, involves the selective extraction and uptake of elements from the local environment and their incorporation into functional structures under the control of an organism [1]. In nature, organisms frequently produce unique ingenious structures with specific beneficial functions (e.g., to protect themselves, to stock and utilize nutrients, to move and work smoothly) by biomineralization.

Fe-/Mn-oxidizing bacteria, Gallionella, Sphaerotilus, Leptothrix, and Clonothrix, are biomineralizing organisms and very often found in ocherous ferromanganese deposits that form in neutral waters of lakes, ponds, swamps, drainage ditches, and springs all over the world [2]. They also inhabit wells and water-distribution systems, where they often cause significant clogging problems $[2,3]$. Their metal-oxidizing ability is a prime example of a biological mechanism for removing trace metals associated with ferromanganese materials, which is important in biogeochemical cycling of the metals [4].

Biologically produced ferromanganese oxides hold promise as catalysts and absorbents for removing hazardous metal ions from water because of their highly porous, amorphous and heterogeneous nature [5]. This ability to recruit Fe and Mn to Leptothrix sheaths finds application in clarification devices for groundwater [6]. Bench-scale biofiltration experiments revealed that biological filters with a pure culture of L. cholodnii SP-6 effectively removed Mn ion from synthetic groundwater [7]. Indeed, some water purification plants in Japan harness this ability to precipitate $\mathrm{Fe}$ and $\mathrm{Mn}$ from groundwater to clean water for drinking [8]. In spite of such favorable use, however, the tons of $\mathrm{Fe}-/ \mathrm{Mn}$-rich precipitates that accumulate in water purification reservoirs are ugly, troublesome waste materials that must be hauled to landfills.

Unexpectedly, our group discovered that this biologically derived, uniquely shaped material is chemically and physically active, and they are now regarded as a promising functional material for innovative development that will also alleviate an environmental waste. We termed this bacterium-associated, Fe-rich material "biogenous iron oxide (BIOX)" [6] and have concentrated on characterizing its properties and its natural and artificial synthesis and determining practical uses. This review focuses on biological and chemical properties of BIOX, in particular, that produced by the genus Leptothrix and functions that have attractive industrial applications. We also occasionally reference data on Gallionella stalks, which have nano-level structures and chemical properties similar to those of Leptothrix sheaths.

\section{Sheath-forming, iron-oxidizing bacteria of the genus Leptothrix}

The genus Leptothrix, which belongs to protobacteria [9], is a group of Gram-negative bacteria $[6,10]$ having a monotrichous, polar, and curvy flagellum [11]. Their rod-shaped cells are relatively large (2.0-3.0 $\times 0.6-1.0 \mu \mathrm{m})$ for bacteria $[6,10,11](L$. cholodnii cells are particularly long $=\sim 5 \mu \mathrm{m}[8])$. Another common physiological character of this genus includes their tendency to form globules of poly-hydroxybutyrate in their cytoplasm as a reserve material, which enables them to survive in nutrient-poor environments $[10,11]$.

The genus Leptothrix is one of the typical heterotrophic microbial

*Corresponding authors: Jun Takada, Core Research for Evolutionary Science and Technology (CREST), Japan Science and Technology Agency (JST) Okayama, Japan, Tel: +81-86-251-8106; E-mail: jtakada@cc.okayamau.ac.jp

Received October 26, 2015; Accepted November 10, 2015; Published November 17, 2015

Citation: Kunoh T, Kunoh H, Takada J (2015) Perspectives on the Biogenesis of Iron Oxide Complexes Produced by Leptothrix, an Iron-oxidizing Bacterium and Promising Industrial Applications for their Functions. J Microb Biochem Technol 7 : 419-426. doi:10.4172/1948-5948.1000249

Copyright: ( $) 2015$ Kunoh T, et al. This is an open-access article distributed unde the terms of the Creative Commons Attribution License, which permits unrestricted use, distribution, and reproduction in any medium, provided the original author and source are credited. 
habitants that form ferromanganese precipitates in oligotrophic and metal-rich hydrospheres $[5,10]$. This genus is characterized by forming a filament-looking microtubular sheath that encases chained cells at an initial stage. A linear arrangement of single cells within the tubular sheath enables the bacteria to form filaments, without any actual enlargement of the cell size [9]. Van Veen et al. [10] observed by light microscopy a chain of about 10 cells of $L$. ochracea leaving their sheath at the rate of $1-2 \mu \mathrm{m} / \mathrm{min}$, as a new hyaline sheath was continuously produced while connected to the extending envelope. According to careful successive phase-contrast observations by Takeda et al. [8], the cells of L. cholodnii elongate and divide regardless of their position in the sheath at 0.01-0.04 $\mu \mathrm{m} / \mathrm{min}$, elongating the sheath at its terminus. However, partially or entirely empty sheaths, in which the bacterial cells are no longer present due to autolysis, are common in nature and culture, as described below.

As of 2011, this genus comprises four recognized species, three of which (L. discophora, L. cholodnii and L. mobilis) have been successfully isolated from the environment and proved to be obligate heterotrophs in pure culture $[12,13]$. The other species, L. ochracea, has proven difficult to culture and thus has been studied in the laboratory in enriched culture $[2,12,14,15]$. Fleming et al. [16] pursued the long-standing enigma of the phylogenetic identity of $L$. ochracea and relations to other species, using single-cell genomics, pyrosequencing, and fluorescence in situ hybridization probe, and found that the small subunit rRNA shared $96 \%$ homology with its closest cultured relative, L. cholodnii. Their findings established that $L$. ochracea was indeed related to the Leptothrix-Sphaerotilus group of morphologically similar, filamentous, sheathed microbes, but the true phylogenetic position of this species as well as its physiological status remains an open question [13]. Leptothrix ochracea is the most common Fe-storing ensheathed bacterium, apparently occurring all over the world in slowly running ferrous Fe-containing water poor in readily decomposable organic material [10].

\section{Structural properties of BIOX produced by Leptothrix}

Microbe-mineral and -metal interactions represent a major intersection between the biosphere and geosphere [17]. In general, bacteria secrete organic exopolymers from their cell surfaces by which the cells coalesce to form a large mass of cells. This process is essential for their survival.

Frequently, a copious amount of lightly brownish microtubules produced by $L$. ochracea can be readily observed with light microscopy in ocherous suspensions scooped from the aquatic environments that L. ochracea predominantly inhabits (Figure 1a). The microtubules are normally $1 \sim 1.5 \mu \mathrm{m}$ wide, but their length can ranges from a few to several hundred micrometers $[3,18]$. In SEM images the outer surface layer of the microtubules is covered with tightly or loosely woven fibrils, while the inner surface has a globular appearance (Figure 1b). The thickness of both layers is largely affected by nutrient status [2]: both are relatively thin in nutrient-poor groundwater but very thick in a nutrient-rich culture medium $[19,20]$.

When isolated strains of Leptothrix are cultured in medium, a chain of bacterial cells is easily distinguished within a thin film of primitive sheath; the cells stain with specific vital stains (Figure 1c). However, the bacterial cells frequently autolyse, regardless of their position in the sheath, within a few days after the culture is started, leading to an increasing number of "empty" tubes (Figure 1b) [21]. Such autolytic cell death seems to occur also in natural environments: over $90 \%$ of the sheaths of $L$. ochracea that are harvested from aquatic environments are empty, usually due to an absence of the bacterial cells $[13,16]$. According to Ghiorse [2], in low-nutrient, Fe-containing enrichment cultures, $L$. ochracea synthesizes and vacates Fe-encrusted sheaths very rapidly. Recently, Kunoh et al. [22] found that cells of Leptothrix sp. OUMS1 (hereafter referred to as OUMS1) [6] and L. cholodnii SP-6 (hereafter SP-6) [4,23] were readily killed by exposure to ultrapure water lacking $\mathrm{Ca}$ ions, suggesting that micro-environmental changes within the sheath that are generated by aqueous-phase cations that are deposited onto the preformed primitive sheath frame that is composed of bacterial organics, may then lower the level of cations, in particular $\mathrm{Ca}$, in the surrounding water. Consequently, peptidoglycans in the cell membrane are hydrolyzed, leading to cell autolysis. The sheaths often fragment at the site of cell autolysis into shorter sheaths, but usually they again elongate when surviving bacterial cells revive and divide $[10,22]$.

Graham et al. [24] showed in a TEM image of cells prepared by freeze-substitution that netlike fibers emerge from the cell membrane of $L$. discophora and completely surround individual cells. They also noted that the sheath of this bacterium was a rugged polymeric matrix able to withstand the mineralization process and the rigors of conventional fixation. On the other hand, in other reports $[2,4,6,11,23,25]$, exopolymer fibrils can be seen near the bacterial cell surface in specimens chemically fixed for TEM. Once released from the cell membrane, countable, long, non-membrane-bound threads extend outward from the entire cell membrane of Leptothrix cells [25]. These threads then assemble to form an immature fibrous layer (primitive sheath) [25]. In specimens prepared by chemical fixation or freezesubstitution, the primitive sheath is visualized as a diffuse, random arrangement of fibrils, which may extend more than $500 \mathrm{~nm}$ above the cell surface, leaving an intervening space between the cell and the sheath $[2,4,6,11,23,25]$.

Extracellular polymers from microbial cells are believed to facilitate microbe-colloid attachment and aggregation of biogenic particles on cell surfaces when biofilms are formed in aquatic environments $[26,27]$. This general perspective raises queries about the significance of this intervening space and whether this space disturbs the interaction between the microbe and aqueous-phase minerals and metals. Heuser and Morone's TEM image of a quick freeze-fracture replica [unpublished data] provides a clear answer to these queries. They kindly allowed us to include a spectacular image of beautifully preserved bacterial exopolymer fibrils of OUMS1 that intervened between the outer cell membrane and the primitive sheath (Figure 2). No threadlike exopolymer projections extended from the outer cell membrane as often observed in chemically fixed specimens [25]. As illustrated in Figure 2, numerous exopolymer fibrils (with $\sim$ 20-50 nm thickness)

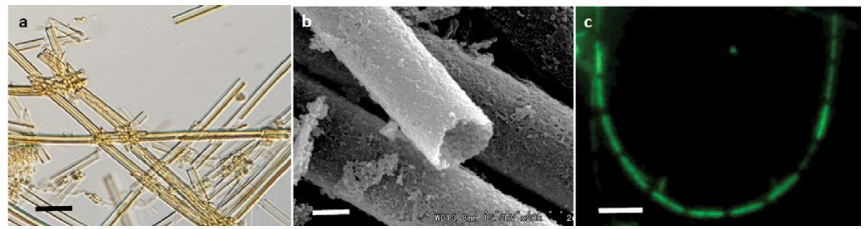

Scale bar=10 $\mu \mathrm{m}$ in (a) (c) and $1 \mu \mathrm{m}$ in (b)

Figure 1: (a) Optical micrograph of microtubular sheaths of Leptothrix in ocherous suspension harvested from a natural spring. (b) Scanning electron micrograph of an empty older sheath of Leptothrix ochracea. (c) Chain of vita Leptothrix cells (fluorescing green) encased by a nearly transparent primitive sheath, detected using LIVE/DEAD vital stain (Molecular Probes, Eugene, OR, USA). 


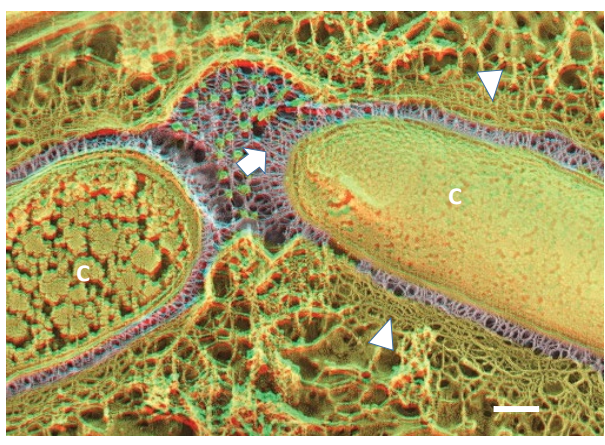

Scale bar $=500 \mathrm{~nm}$

Figure 2: TEM image of freeze-fracture replica of exopolymer fibrils (arrow) extending from the outer membrane of cells (C) and sheath frame (arrowheads) of Leptothrix sp. OUMS1, photographed in 3D "anaglyph form (courtesy of Professor Heuser and Dr. Morone, Kyoto University).

emerge from the outer cell membrane to occupy the disputant space and further extend to coalesce with each other (approximate thickness of 100-200 nm) and form the basic skeleton of the primitive sheath. Unlike chemical fixation and freeze-substitution preparations, the freeze-fracture replica method does not use any chemical fixative, dehydrating or resin-infiltration agents; thus, the freeze-fracture replica method almost completely excludes artifacts caused by the organic chemicals used in traditional preparations. Therefore, Figure 2 is a convincingly close illustration of the in situ spatial association of the bacterial exopolymer fibrils with the sheaths and strong evidence that the sheath frame construction originates from coalescing bacterial exopolymers.

The image in Figure 2 raises another query: Why does this intervening space appear in specimens prepared by conventional chemical and freeze-substitution fixations? According to Graham and Beveridge [28], organic components of bacterial cells readily leach out during fixation, dehydration, and resin infiltration during both methods, although the degree of leaching varies with the bacterial species. Considering their report, newborn exopolymer fibrils of Leptothrix could be very sensitive to these organic agents, while coalesced fibrils in the primitive sheath skeleton could be tolerant, probably due to the initiation of metal encrustation. This prediction is supported by the description of Chan et al. [15] that mineralization protects the polymers from degradation and contributes to maintaining a long-term carbon pool in aqueous systems.

In a detailed analysis of extracellular polymers of Shewanella oneidensis using conventional electron microscopy with imaging at room temperature and cryogenic electron microscopy with imaging in a close-to-natural hydrated state, Dolnalkova et al. [17] concluded that the traditional sample preparation did not preserve the native morphology of microbiological components, especially extracellular polymers, well; dehydration-based sample preparation resulted in collapse of the polymers into filamentous structures. Notably, when fully hydrated polymers on a carbon grid were subjected to relatively slow dehydration by sublimation induced in situ under vacuum inside the TEM column, assisted by a slight temperature increase, they revealed surprising pliability as the polymers began to collapse and condense into fiber-like structures that increasingly stretched between the areas where the material was anchored on the grid support. Their analytical data apparently indicate that the exopolymers are quite delicate and that their native morphology is readily damaged by temperature as well as the use of fixative, dehydration and resin infiltration agents. Howard and Aist [29] showed that the hyphal tip morphology of a Fusarium fungus was greatly different between freezesubstitution and conventional chemical fixation; smooth membrane cisternae, two types of apical vesicles and oriented microtubules, and four distinct layers in primary cell wall found in hyphal tips that were freeze-substituted were not found after chemical fixation. Dolnalkova et al. [17] also emphasized that dehydration-induced polymer collapse could lead to inaccurate spatial relationships and thus affect conclusions regarding the nature of interactions between microbial extracellular polymers and their environment. All these earlier papers strongly remind us that specimen preparation protocols for electron microscopy (use of fixation and dehydration agents and environmental factors such as temperature, $\mathrm{pH}$, and pressure) are extremely important considerations for interpreting real native interactions associated with microbial structures.

Keeping this invaluable reminder in mind, in TEM images of the chemically fixed specimens, two distinct layers-an inner layer of densely woven fibrils and an outer layer of loosely assembled fibrilsare usually distinguishable in mature sheaths after the progressive deposition of the inorganics $[8,23,25]$. The outer loosely woven fibrillar layer most likely reflects the progressive excretion of exopolymer fibrils from cells as the fibrils extend outward through the inner layer.

The matrix of the Leptothrix sheath consists of a disordered assembly of primary particles of $\sim 3 \mathrm{~nm}$ diameter and has a high porosity and large specific surface areas, similar to that of Gallionella stalk fibers $[3,30,31]$. These characters are considered to be somehow associated with a high catalytic reactivity of BIOX as described later.

Axenic cultures of isolated strains of Leptothrix spp. very often lose their sheath-forming capacity after growth and repeated transfers on culture media $[2,4,10,32,33]$. A thus-derived sheathless mutant still releases exopolymer fibrils from its cell surface, but the cells keep dividing and extending without forming sheath-like structures [32], suggesting that the repeated transfer of the isolates in artificial medium readily causes deletion of a gene(s) or a failure of gene expression. Although the initial parallel arrangement and/or simple intermingling of coalesced fibrils holds a key for subsequent construction of the primitive sheath skeleton $[25,32]$, its trigger remains unknown.

\section{Chemical properties of BIOX produced by Leptothrix}

In 1984 Ghiorse [2] noted in his review that little was known of the chemical composition or the underlying organic matrix structure of Leptothrix sheaths. Since then, a lot of information on the ultrastructure at the micron and nano levels and on the chemical composition of the sheaths has been detailed with the quantum progression of electron microscopy and chemical analysis technology.

Chan et al. [34] reported that organic polymers could play important roles in ecosystems by accumulating biologically important elements and that microbial polymers could scavenge iron oxide particles and induce crystallization of unexpected phases. Many studies have proved that the sheath matrix of Leptothrix is composed of a complicated hybrid of bacterial exopolymers and aquatic metals $[2,3,11,21,23,25,35,36]$. Alkaline bismuth [11,25], ruthenium red [2], and FITC-conjugated lectin stains [11,37] have been used to detect saccharic materials, acidic polymers, and various monosaccharides such as glucose, mannose, galactose, and $N$-acetyl galactosamine, respectively, in sheaths of Leptothrix spp. In addition, proteinaceous materials in sheaths have been shown using various 
specific reagents for amino acids such as "Ruby" for general amino acids, R-phycoerythrin-labeled antibody for the $-\mathrm{SH}$ group, and a fluorescein-labeled $\mathrm{NH}_{2}$ kit for $\mathrm{NH}_{2}$ group (Figure 3; unpublished data). Emerson and Ghiorse [23] showed that the basic skeleton of L. cholodnii SP-6 was composed of $6.5 \mathrm{~nm}$ wide fibrils containing heteropolysaccharides and proteins and that the skeleton contained a relatively high concentration of cysteine residues, suggesting that disulfide bonds play an important role in maintaining the structures of the sheath skeleton. Subsequently, they degraded the sheath of SP-6 using various chemical denaturants and lytic enzymes, and analyzed the molecules that compose the basic fibrils that provide the integral structural element of the sheath skeleton [36]. They confirmed that the fibrils consisted of high-molecular-weight heteropolysaccarideprotein complexes and hypothesized that $20-25 \%$ proteins in the fibril complexes could provide interfibril cross-linking. Similarly, Takeda et al. [38] degraded the sheaths of SP-6 with lysozyme/SDS/EDTA for chemical analysis of their components and detected amino acids such as glycine and cysteine and several types of hyaluronic acids in the degradation products of the sheath materials. After identification of linkages of individual protein and sugar units, they concluded that the sheath material was constructed from a polysaccharidecored peptide: a structural glycoconjugate that is a straight-chained amphoteric heteropolysaccharide linked with glycine and cysteine. In a subsequent detailed study [5], this glycoconjugate was proven to be a glycosaminoglycan consisting of a pentasaccharide repeating unit that was substoichiometrically esterified with 3-hydroxypropioic acid and stoichiometrically amidated with acetic acid and glycyl-L-cysteine. These reports show that sulfhydryl glycoconjugates are a major core organic component that can contribute to the structural integrity of the sheath skeleton.

Earlier energy dispersive x-ray spectroscopy (EDX) analyses of the Leptothrix sheaths showed that $\mathrm{Fe}, \mathrm{Si}$, and $\mathrm{P}$ (their approximate rate in atomic \%: 70-80:15-20:5-10) and often a low atomic percentage of $\mathrm{Ca}$ are the major inorganics in sheaths, whether naturally harvested or cultured $[3,11,18,25,35,39]$. Interestingly, this rough ratio does not vary greatly by location or season of the sheath harvest. Furutani et al. [25] confirmed this initial construction of the sheath skeleton of OUMS1 by TEM/EDX and showed that aqueous-phase inorganics such as $\mathrm{Fe}, \mathrm{Si}$, and $\mathrm{P}$ are first deposited onto the outer, loosely woven fibrils of the primitive sheaths, which causes the electron density of the entire sheaths to increase with extended culture, consist with earlier

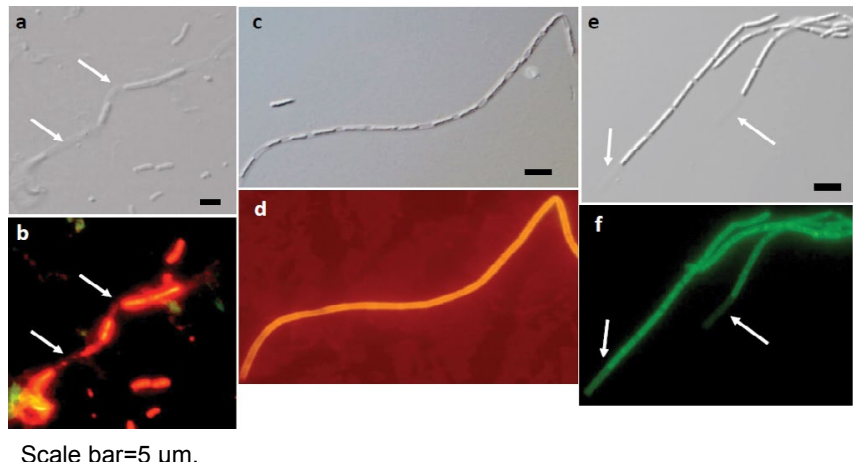

Figure 3: Detection of amino acids in 1-day old Leptothrix sheaths. a, c, e: Differential interference contrast micrographs of sheaths encasing chained cells. b, d, f: Positive responses for general amino acids using Ruby stain, - SH group using R-phycoerythrin-labeled antibody, and amino group using a fluorescein-labeled $\mathrm{NH}_{2}$ kit, respectively, in the sheaths in a, c, and e. descriptions on the timing and initial location of Fe or Mn deposition in Leptothrix sheaths $[2,10]$.

Hashimoto et al. [31] also detected $\mathrm{Fe}-\mathrm{O}-\mathrm{Fe}$ and $\mathrm{Fe}-\mathrm{Si}$ bonds in Leptothrix sheaths. Using a combination of high-energy X-ray diffraction and reverse Monte Carlo simulation, they also presented a configuration coordinate model of $\mathrm{Fe}$ and $\mathrm{Si}$ components in the sheath of L. ochracea: a framework of corner- and edge-sharing distorted $\mathrm{FeO}_{6}$ octahedral units with isolated $\mathrm{SiO}_{4}$ tetrahedral units in the framework. Similarly, in Gallionella stalk fibers, bands characteristic of vibrational modes assigned to Fe-O-H, P-O-H, Si-O-H, Si-O-Fe, and P-O-Fe bonds were detected by EDX and Fourier transform infrared spectroscopy [30]. All these reports indicate that inorganic elements detected are not simply attached on a BIOX matrix but bound one another to form chemical bonds. Moreover, Suzuki et al. [35] examined the structural and spatial associations of $\mathrm{Fe}$ with $\mathrm{O}$ and $\mathrm{C}$ in the outer coat fibers of L. ochracea sheaths by high-angle annular dark-field scanning electron microscopy and electron energy loss spectroscopy and demonstrated a clear image of a central $\mathrm{C}$ core of bacterial origin and aquatic $\mathrm{Fe}$ interacting with $\mathrm{O}$ at the surface of the core, which were substantially similar to the stalk fibers of Gallionella ferruginea [40].

All these data evidently indicate that the basic composition of BIOX, Leptothrix sheaths and Gallionella stalks is a complicated organic/inorganic hybrid material [15,25,35].

\section{Proposed modes of Fe/Mn encrustation of sheaths}

In nature, iron occurs mostly in two oxidation states $(+2$ or +3$)$, forming a number of mineral phases, including oxides, carbonates, silicates and sulfides. Which form of iron predominates depends greatly on prevailing physicochemical conditions such as $\mathrm{pH}$, oxygen concentration and redox potential in the environment [12]

It has long been accepted that the electron that is generated during biogenic oxidation of aqueous-phase $\mathrm{Fe}$ (II) to $\mathrm{Fe}(\mathrm{III})$ or $\mathrm{Mn}$ (II) to $\mathrm{Mn}(\mathrm{IV})$ is essential for autotrophical or mixotrophical metabolism of Leptothrix as an energy source [10,15,33,34,41-43]. The Fe-/Mnoxidizing proteins of $L$. discophora SS-1 have been reported to be excreted from bacterial cells in association with exopolymers [41,4446]. The Mn-oxidizing activity of Leptothrix cells that converts Mn(II) to $\mathrm{Mn}(\mathrm{IV})$ is well documented [47]. Emerson and Ghiorse [4] identified a 108-kDa Mn-oxidizing protein in a concentrated spent culture of SP6 . Similarly, a Fe-oxidizing protein with a huge molecular weight $(\sim 150$ $\mathrm{kDa}$ ) was identified in the spent culture of SS-1 [41]. In several bacteria including SS-1, copper-dependent enzymes play a role in $\mathrm{Mn}$ (II) oxidation [47]. Fe(II) is also involved in stimulating Mn-oxidizing activity in SS-1 cells [48]. Because Fe(II) readily reacts abiotically with oxygen under near-neutral $\mathrm{pH}$ conditions, the quantitative significance of microbial $\mathrm{Fe}$ (II) oxidation in circumneutral $\mathrm{pH}$ environments was unclear until recently. Vollrath and colleagues $[49,50]$ reported that the rate of microbial $\mathrm{Fe}(\mathrm{II})$ oxidation by L. cholodnii Appels was significantly higher compared with abiotic oxidation at an early stage and was highly influenced by temperature and availability of oxygen. Taken together, the $\mathrm{Mn}$-/Fe-oxidizing activity of Leptothrix cells is greatly affected by environmental conditions such as temperature, availability of oxygen, and the concentration of other ions.

The metal encrustation of Leptothrix sheaths is considered to be the result of an interaction between active groups on bacterial organic components of the sheath skeleton with aqueous-phase inorganics [41]. Chan et al. [15] noted significantly that the reduced carbon in polymers is a potential electron donor for microbes, $\mathrm{Fe}$ oxides are electron acceptors for Fe-oxidizing microbes, and that 
the creation and destruction of mineralized organics can profoundly affect solution geochemistry, since Fe oxides and natural organics are the most significant sorbents of metals. According to an earlier investigation on sites of metal deposition in the plasma membrane of Bacillus subtilis [51], the active groups of organics in the membrane, in particular carbonyl groups provide the major site of metal deposition. Furthermore, a cationic bridging mechanism is thought to involve the bridging of silicate anions by the bacterial plasma membrane [52]. The sheath material of Leptothrix has been reported to contain organics such as polysaccharides, proteins and lipids whose active groups are readily expected to play critical roles to bind aqueous-phase cations $[9,23,25,38]$. Nearly uniform distribution of inorganics was shown in the Leptothrix sheaths, which were harvested from natural environments [35] or a relatively long-term (7-14 days) culture [4,6]. In addition, Chan et al. [15] showed a strong correlation between acidic polysaccharides with carboxyl functional groups and the iron oxyhydroxide distribution patterns in Leptothrix sheath and Gallionella stalks. All these data suggest that negatively charged active groups of saccharic and proteinaceous acidic components in sheath exopolymers of bacterial origin contribute to attract aqueous-phase metal ions $[2,15,53]$.

Although careful approaches to study the interactions between bacterial exopolymers and metal ions in aqua-environments have promoted our understanding on this matter, the structural relationship of how metal-oxidizing factors, either for $\mathrm{Fe}$ or $\mathrm{Mn}$, are associated with the complex organic/inorganic composites such as Leptothrix sheaths remains to be elucidated in more detail [13].

To date, many researchers have cultured several isolated strains of Leptothrix in media with varied $\mathrm{Fe}$ sources such as ferric compounds $\left(\mathrm{FeCl}_{2}, \mathrm{Fe}\right.$-ammonium citrate, or $\left.\mathrm{FeSO}_{4}\right), \mathrm{FeCl}_{3}$, and $\mathrm{Fe}$ plates or powder $[6,20,49,54]$ toward understanding the mechanism of $\mathrm{Fe}$ oxidization and deposition on sheaths. Emerson et al. [13] emphasized that abiotic Fe oxidation in fully oxygenated water at circumneutral $\mathrm{pH}$ is very rapid (half-life $<1 \mathrm{~min}$ ) and that the instantaneous precipitation of $\mathrm{Fe}$ oxyhydroxides that resulted from $\mathrm{Fe}$ oxidation could potentially entomb a cell in a metal oxide cluster. As is well known, the behavior of ionic $\mathrm{Fe}$ in liquid has not been satisfactorily explained, because $\mathrm{Fe}$ ions can form hydroxide/oxyhydroxide complexes and diverse salts with other elements in aquatic systems [55]. The behavior of dissolved metals in natural bodies of water is strongly influenced by particular inorganic and organic materials [56], suggesting complex interactions of various metal-complexing agents in aquatic systems with microbes and/or their constituent polymers. It is therefore hypothesized that microbiologically produced Fe-complexing ligands may play critical roles in both the delivery of $\mathrm{Fe}$ (II) to oxidates and the limited $\mathrm{Fe}(\mathrm{III})$ oxyhydoxide crystallinity observed within the biofilm [57]. Such complicated interactions are also sure to occur when Leptothrix is grown in $\mathrm{Fe}$-containing media amended with various inorganics and organic components such as peptone and vitamins. Hedrich et al. [12] noted that ferrous iron was stable in anoxic environments, but was susceptible to spontaneous chemical oxidation by molecular oxygen. Focusing on this finding, Kunoh et al. [58] examined interactions of $\mathrm{Fe}(\mathrm{II})$ and $\mathrm{Fe}(\mathrm{III})$ in shake culture and found that $\mathrm{Fe}(\mathrm{II})$ was promptly converted to $\mathrm{Fe}$ (III) precipitation and that the precipitated $\mathrm{Fe}(\mathrm{III})$ directly adhered to the existing sheath surfaces. Although they failed to determine how this direct adherence interfered with the proposed modes of sheath encrustation, we must consider this phenomenon when investigating the interactions between bacterial exopolymers and metal ions, particularly in shake cultures.

\section{Unique functions of BIOX applicable to industrial purposes}

The mechanisms of biological systems for producing extraordinary inorganic structures and morphologies are of great interest for engineering novel materials [34]. To date, studies of BIOX have mostly been implemented from bacteriological and geochemical perspectives. During our past basic and general studies of BIOX, we noticed unique functions of BIOX with great promise for industrial application. Since then, our studies have been directed toward the development of new industrially useful, functional materials under multidiscipline collaborations in solid-state chemistry and material sciences. This section outlines the results we have obtained using BIOX of $L$. ochracea as a target material.

Lithium-ion battery anode material: Lithium-ion batteries with high-rate capabilities are in high demand for use in portable electric devices, electric vehicles, and electric power storage. To meet future needs for an increasing variety of applications, further exploration of new electrode materials is a very important issue [59]. Hashimoto et al. [60] first reported an interesting experimental result that microtubuleshaped BIOX composed of amorphous $\mathrm{Fe}$ (III)-based oxide nanoparticles exhibited a dual-directional conversion between Fe(III) and $\mathrm{Fe}(0)$ via $\mathrm{Fe}(\mathrm{II})$ in the anode material for lithium-ion batteries. Furthermore, Sakuma et al. [61] showed that $\mathrm{Fe}(\mathrm{III}) / \mathrm{Fe}(\mathrm{II})$ conversion reactions dominated in a voltage range of 1.5-4.0 V when washed and air-dried BIOX was used as the anode material. Considerably higher cyclability, a cycle capacity exceeding $70 \mathrm{mAh} / \mathrm{g}$ at a current of 1670 $\mathrm{mA} / \mathrm{g}$, was also found. Our investigations to enhance the electric power and cyclability of BIOX anode materials is ongoing.

Catalyst enhancer: Immobilization methods for enzymes often have an impact on the catalytic activity, stereoselectivity, thermostability and recyclability of the enzymes [18]. Sakai et al. [3] and Ema et al. [18] chemically modified BIOX with silane coupling agents to produce organic-inorganic hybrid materials, which were then used as immobilization supports for enzymes. They found that the immobilized lipases had a very high turnover frequency in kinetic resolution of secondary alcohols. The amorphous and porous texture of BIOX consisting of nanoparticles probably created a surface suitable for immobilization of catalysts. Similarly, Mandai et al. [62] attempted to modify the surface of BIOX with trialkoxysilanes as organic crosslinkers bearing various functional groups at their termini, which were capable of coordinating palladium for its attachment on BIOX. Using such a modified BIOX, they showed that palladium immobilized on BIOX bearing a specific organic cross-linker delivered the desired biaryl products in sufficient yields in the Suzuki-Miyaura coupling reactions under solvent-free conditions. These BIOX-immobilized catalysts are recyclable without significant loss of activity. Hashimoto et al. $[63,64]$ prepared acidic amorphous silica from BIOX pre-heated at $500^{\circ} \mathrm{C}$ in a hydrogen gas flow after a subsequent 3-day treatment in $1 \mathrm{M}$ hydrochloric acid with stirring to dissolve Fe from BIOX. Interestingly, thus-prepared acidic amorphous silica microtubes also promoted organic reactions such as ring opening of epoxides and Friedel-Crafts-type alkylations, more effectively than common silica materials did. Although the reason why BIOX and derived materials unexpectedly work as catalyst enhancers is still unclear, the surface and/or basic texture structures, in particular synergetic effects of $\mathrm{Si}$, seem to be a key in this matter.

Porcelain and pottery pigments: Ceramic artists always seek bright-color pigments for drawing and/or painting. Hematite-based red pigments, so-called bengala, have been commonly used as overglaze pigments on porcelain, lacquer wares, asphalt roads, cosmetics, and 
building materials because of their excellent tinting and their smaller particles $[65,66]$. A common problem with hematite from natural ores and industrially synthesized hematite, which are used widely in red overglaze pigments, is that their color fades when the hematite grains grow under heat treatment. Therefore, it is highly desirable that the hematite powder for overglaze pigments not only provides a beautiful color but also be thermostable and resistant to grain growth during heat treatment [65]. The following BIOX pigments cleared this longstanding puzzle.

Hashimoto et al. $[65,67]$ drew attention to the basic structural and chemical properties of BIOX and attempted to create a novel bright color pigment for porcelain. They heated naturally harvested BIOX at $600-1000^{\circ} \mathrm{C}$ in air and discovered that the color tone of BIOX changed depending on the temperature: dark brown, orange, red, and dark gray from low to high temperatures. The most beautiful yellowish-red sample with a unique microstructure was obtained by heating at $800^{\circ} \mathrm{C}$. Importantly, its color did not fade even with reheating at $800^{\circ} \mathrm{C}$, the routine firing temperature for overglaze pigments on porcelain. The sample consisted of crystalline hematite particles ( $\sim 40 \mathrm{~nm}$ diameter) with slightly longer unit-cell axis parameters than those of pure hematite. Interestingly, the particles were covered with an amorphous silicate phase ( $\sim \mathrm{nm}$ thickness) and were intricately interconnected into sheath microtubules. After experimental XRD, TEM, SEM, and colorimetric analyses, they concluded that the attractive color of this material was due to its small particle size $(\sim 40 \mathrm{~nm})$, nanocomposition of hematite and amorphous silicate, and microtubular structure.

In addition, our preliminary data show that a bright yellow pigment is also produced by culturing OUMS1 at low $\mathrm{pH}$ and with ambient carbon dioxide, suggesting that BIOX has a profound potential for creating new attractive pigments for ceramic engineering.

Others: Iron oxides with a spinel-type structure are one of the most widely used magnetic materials. For instance, needle-shaped maghematite is used for magnetic recording and spherical $\mathrm{Fe}_{3} \mathrm{O}_{4}$ for copy machine toner [68]. At the industrial level, these particles are obtained from ferric oxyhydroxide $(\mathrm{FeOOH})$ nanoparticles produced by wet chemical synthesis [69]: heat treatment for dehydration, reduction, and slow oxidation of $\mathrm{FeOOH}$ to produce magnetic particles that maintain their original particle shape [68,70]. As described already, the BIOX microtubules are composed of Si-containing ferric hydroxide that yields a broad $\mathrm{x}$-ray diffraction pattern similar to 2-line ferrihydrite. Hashimoto et al. [70] created nanocrystalline $\mathrm{Fe}_{3} \mathrm{O}_{4}$ with a spinel-type structure in a nanocrystalline silicate matrix from BIOX using a moderate heat treatment in a reductive atmosphere. Thusprepared magnetite-silicate nanocomposites are used as low-cost alternatives for chemically synthesized maghematite and spherical $\mathrm{Fe}_{3} \mathrm{O}_{4}$

Interestingly, novel sheath materials with varied Si contents can be produced in culture by an isolated strain of Leptothrix [71]. Thus, the bacteria and their sheaths are very attractive for artificially creating very important industrial materials with novel functions and solving critical environmental and commercial problems by harnessing our basic knowledge of iron-oxidizing bacteria and their products.

\section{Concluding Remarks}

As is well known, microbes often create mineral deposits that feature elaborate structures and unique compositions. Bacteria belonging to the genus Gallionella are another group of ubiquitous inhabitants of ocherous deposits that form in bodies of freshwater
[3]. They form a uniquely twisted extracellular iron oxide-encrusted bundle of fibers (commonly called a twisted stalk) that is similar to the Leptothrix sheaths and consists of Fe-based amorphous organic/ inorganic composites. Although the visual form of BIOX that Gallionella produces is obviously different from the microtubular Leptothrix BIOX, their basic nano-scaled structural and chemical characters are quite similar $[30,40,72]$. It is noteworthy that both BIOXs have practical industrial functions, suggesting that such functions are largely dependent on their structural and chemical characteristics at the micron or nano level of basic structures of BIOX.

Another noteworthy feature of BIOX is that it can be continuously produced at a high rate and at extremely low cost in a natural hydrosphere where groundwater outwells. Even in our small plant with a $10^{4} \mathrm{~L}$ volume tank on the university farm, $\sim 150 \mathrm{~g}$ (dry mass) of BIOX and $\sim 6.2 \times 10^{3} \mathrm{~L}$ of Fe-free water can be obtained in a day simply by exposing that amount of natural groundwater to the outside environments (unpublished data). Thus, BIOX is, obviously, an extremely cost-effective, beneficial material.

As we have accumulated knowledge on the relationship between the chemical composition of the water supplied by isolated strains of Leptothrix in culture and the chemical and physical characters of the product, we have explored the development of a synthetic process for the fine control of particle morphology, chemical composition, particle aggregation, and other factors associated with creating BIOXanalogous materials. The practical applications that we described highlight the unexplored frontier that BIOXs represent in solid-state chemistry and materials science. We believe that the development of artificial synthetic processes for BIOX analogues is essential and urgent because a constant supply system of qualitatively characterized and quantitatively determined raw material is apparently critical for industrial applications of BIOX.

\section{References}

1. Mann S (2001) Biomineralization-Principles and concepts in bioinorganic materials chemistry. Oxford University Press, Oxford, UK

2. Ghiorse WC (1984) Biology and iron- and manganese-depositing bacteria. Ann Rev Microbiol 38: 515-550.

3. Sakai T, Miyazaki Y, Murakami A, Sakamoto N, Ema T, et al. (2010) Chemical modification of biogenous iron oxide to create an excellent enzyme scaffold. Org Biomole Chem 8: 336-338.

4. Emerson D, Ghiorse WC (1992) Isolation, cultural maintenance and taxonomy of a sheath-forming strain of Leptothrix discophora and characterization of manganese-oxidizing activity associated with the sheath. Appl Environ Microbiol 58: 4001-4010.

5. Takeda M, Kondo K, Yamada M, Koizumi J, Mashima T, et al. (2010) Solubilization and structural determination of a glycoconjugate which is assembled into the sheath of Leptothrix cholodnii. Int'l J Biol Macromol 46: 206-211.

6. Sawayama M, Suzuki T, Hashimoto H, Kasai T, Furutani M, et al. (2011) Isolation of a Leptothrix strain, OUMS1, from ocherous deposits in groundwater. Curr Microbiol 63:173-180.

7. Burger MS, Mercer SS, Shupe GD, Gagnon GA (2008) Manganese removal during bench-scale biofiltration. Water Res 42: 4733-4742.

8. Takeda M, Kawasaki Y, Yamada M, Koizumi J, Umezu T, et al. (2012) Patterns of sheath elongation, cell proliferation, and manganese(II) oxidation of Leptothrix cholodnii. Arch Microbiol 194: 667-673.

9. Spring S (2006) The genera Leptothrix and Sphaerotilus. Prokaryotes 5: 758777 .

10. Van Veen WL, Mudler EG, Deinema MH (1978) The Sphaerotilus-Leptothrix group of bacteria. Microbiol Rev 42: 329-356.

11. Furutani M, Suzuki T, Ishihara H, Hashimoto H, Kunoh H, et al. (2011) 
Citation: Kunoh T, Kunoh H, Takada J (2015) Perspectives on the Biogenesis of Iron Oxide Complexes Produced by Leptothrix, an Iron-oxidizing Bacterium and Promising Industrial Applications for their Functions. J Microb Biochem Technol 7: 419-426. doi:10.4172/1948-5948.1000249

Assemblage of bacterial saccharic microfibrils in sheath skeleton formed by cultured Leptothrix sp. strain OUMS1. J Marine Sci : Res Develop S5: 1-5

12. Hedrich S, Schlömann M, Johnson DB (2011) The iron-oxidizing protobacteria. Mycology 157: 1661-1564.

13. Emerson D, Flemming EJ, McBeth JM (2010) Iron-oxidizing bacteria: An environmental and genomic perspective. Annu Rev Microbiol 64: 561-583.

14. Hashimoto H, Yokoyama S, Asaoka H, Kusano Y, Ikeda Y, et al. (2007) Characteristics of hollow microtubes consisting of amorphous iron oxide nanoparticles produced by iron oxidizing bacteria, Leptothrix ochracea. J Magnetism Magnetic Mater 310: 2405-2407.

15. Chan SC, Fakra CS, Edwards CD, Emerson D, Banfield FJ (2009) Iron oxyhydroxide mineralization on microbial extracellular polysaccharides. Geochim Cosmochim Acta 73: 3807-3818.

16. Fleming EJ, Langdon AE, Martinez-Garcia M, Stepanauskas R, Poulton NJ, et al. (2011) What's new is old: resolving the identity of Leptothrix ochracea using cell genomics, pyrosequencing and FISH. PLoS One 6: 1-10.

17. Dohnalkova AC, Marshall MJ, Arey BW, Williams KH, Buck EC, et al. (2011) Imaging hydrated microbial extracellular polymers: comparative analysis by electron microscopy. Appl Environ Microbiol 77: 1254-1262.

18. Ema T, Miyazaki Y, Kozuki I, Sakai T, Hashimoto H, et al. (2011) Highly active lipase immobilized on biogenous iron oxide via an organic bridging group: the dramatic effect of the immobilization support on enzymatic function. Green Chem 13: 3187-3195.

19. Suzuki T, Ishihara M, Furutani M, Shiraishi T, Kunoh H, et al. (2012) A novel method for culturing of Leptothrix sp. strain OUMS1 in natural conditions. Minerals 2: 118-128.

20. Suzuki T, Kunoh T, Nakatsuka D, Hashimoto H, Tamura K, et al. (2015) Use of iron powder to obtain high yields of Leptothrix sheaths in culture. Minerals 5:335-345

21. Suzuki T, Ishihara H, Toyoda K, Shiraishi T, Kunoh H, et al. (2013) Autolysis of bacterial cells leads to formation of empty sheath by Leptothrix spp. Minerals 3: 247-257.

22. Kunoh T, Suzuki T, Shiraishi T, Kunoh H, Takada J (2015) Treatment of Leptothrix cells with ultrapure water poses a threat to their viability. Biology 4: $50-66$

23. Emerson D, Ghiorse WC (1993) Ultrastructure and chemical composition of the sheath of Leptothrix discophora SP-6. J Bacteriol 175: 7808-7818.

24. Graham LL, Harris R, Villinger W, Beveridge TJ (1991) Freeze-substitution of Gram-negative eubacteria: general cell morphology and envelop profiles. $J$ Bacteriol 173: 1623-1633.

25. Furutani $M$, Suzuki $T$, Ishihara $H$, Hashimoto $H$, Kunoh $H$, et al. (2011) Initial assemblage of bacterial saccharic fibrils and element deposition to form an immature sheath in cultured Leptothrix sp. strain OUMS1. Minerals 1: 157-166.

26. Boonfueng TL, Yee AN, Hahn D, Ndiba PK (2009) Zn-sorption mechanisms onto sheathed Leptothrix discophora and the impact of the nanoparticulate biogenic Mn oxide coating. J Colloid Interface Sci 333: 439-447.

27. Templeton AS, Trainor TP, Traina SJ, Spormann AM, Brown Jr GE (2001) $\mathrm{Pb}$ (II) distributions at biofilm-metal oxide interfaces. Proc Nat'l Acad Sci 98 : 11897-11902.

28. Graham LL, Beveridge TJ (1990) Evaluation of freeze-substitution and conventional embedding protocols for routine electron microscopic processing of eubacteria. J Bacteriol 172: 2141-2149.

29. Howard RJ, Aist JR (1979) Hyphal tip cell ultrastructure of the fungus Fusarium: improved preservation by freeze-substitution. J Ultrastru Res 66: 224-234.

30. Suzuki T, Hashimoto H, Itadani A, Matsumoto N, Kunoh H, et al. (2012) Silicon and phosphorus linkage with iron via oxygen in the amorphous matrix of Gallionella ferruginea stalks. Appl Environ Microbiol 78: 236-241.

31. Hashimoto H, Fujii T, Kohara S, Asaoka H, Kusano Y, et al. (2012) Amorphous structure of iron oxide of bacterial origin. Mater Chem Phys 137: 571-575.

32. Ishihara H, Suzuki T, Hashimoto H, Kunoh H, Takada J (2013) Initial parallel arrangement of extracellular fibrils holds a key for sheath frame construction by Leptothrix sp. strain OUMS1. Minerals 3: 73-81.

33. Adams LF, Ghiorse WC (1986) Physiology and ultrastructure of Leptothrix discophora SS-1. Arch Microbiol 145: 126-135.
34. Chan CS, de Stasio G, Welch SA, Girasole M, Frazer BH, et al. (2004) Microbial polysaccharides template assembly of nanocyrstal fibers. Science 303: 16561658.

35. Suzuki T, Hashimoto H, Ishihara H, Kasai T, Kunoh H, et al. (2011) Structura and spatial associations between $\mathrm{Fe}, \mathrm{O}$, and $\mathrm{C}$ in the network structure of the Leptothrix ochracea sheath surface. Appl Environ Microbiol 77: 7873-7875.

36. Emerson D, Ghiorse WC (1993) Role of disulfide bonds in maintaining the structural intergrity of the sheath of Leptothrix discophora SP-6. J Bacteriol 175: 7819-7827.

37. Lawrence JR, Swenhone GD, Leppard GG, Araki T, Zhang X, et al. (2003) Scanning transmission $\mathrm{x}$-ray, laser scanning, and transmission electron microscopy mapping of the exopolymeric matrix of microbial biofilms. App Environ Microbiol 69: 5543-5554.

38. Takeda M, Makita H, Ohno K, Nakahara Y, Koizumi J (2005) Structural analysis of the sheath of a sheathed bacterium, Leptothrix cholodnii. Int'I J Biol Macromole 37: 92-98.

39. Kennedy CB, Scott SD, Ferris FG (2003) Ultrastructure and potential subseafloor evidence of bacteriogenic iron oxides from Axial Volcano, Juan de Fuca Ridge, north-east Pacific Ocean. FEMS Microbiol Ecol 43: 247-254.

40. Suzuki T, Hashimoto H, Matsumoto N, Furutani M, Kunoh H, et al. (2011) Nanometer-scale visualization and structural analysis of the inorganic/organic hybrid structure of Gallionella ferruginea twisted stalks. Appl Environ Microbiol 77: $2877-2881$.

41. Corstjens PL, de Vrind JP, Westbroek, de Vrind-de Jong EW (1992) Enzymatic iron oxidation by Leptothrix discophora: identification of an iron-oxidizing protein. Appl Environ Microbiol 58: 450-454.

42. de Vrind-de Jong EW, Corstjens PL, Kempers ES, Westbroek P, de Vrind JP (1990) Oxidation of manganese and iron by Leptothrix discophora: Use of $N, N, N^{\prime}, N^{\prime}$-tetramethyl-p-phenylenediamine as an indicator of metal oxidation. Appl Environ Microbiol 56: 3458-3462.

43. Rentz JA, Kraiya C, Luther-III GW, Emerson D (2007) Control of ferrous iron oxidation within circumneutral microbial iron mates by cellular activity and autocatalysis. Environ Sci Technol 41: 6084-6089.

44. Boogerd FC, de Vrind JP (1987) Manganese oxidation by Leptothrix discophora. J Bacteriol 169: 489-494.

45. Adams LF, Ghiorse WC (1987) Characterization of extracellular $\mathrm{Mn}^{2+}$-oxidizing activity and isolation of $\mathrm{Mn}^{2+}$-oxidizing protein from Leptothrix discophora SS-1. J Bacteriol 169: 1279-1285

46. Adams LF, Ghiorse WC (1988) Oxidation state of Mn in the Mn oxide produced by Leptothrix discophora SS-1. Geochim Cosmochim Acta 52: 2073-2076.

47. Zhang J, Lion LW, Nelson YM, Shuler ML, Ghiorse WC (2002) Kinetics of $\mathrm{Mn}$ (II) oxidation by Leptothrix discophora SS-1. Geochimica Cosmochimica Acta 65: 773-781.

48. El Gheriany IA, Bocioaga D, Hay AG, Ghiorse WC, Shuler ML, et al. (2009) Iron requirement for $\mathrm{Mn}(\mathrm{II})$ oxidation by Leptothrix discophora SS-1. Appl Environ Microbiol 75: 1229-1235.

49. Vollrath S, Behrends T. Koch CB, van Cappellen P (2013) Effects of temperature on rates and meinral products of microbial Fe(II) oxidation by Leptothrix cholodnii at microaerobic conditions. Geochim Cosmochim Acta 108: 107-124.

50. Vollrath S, Behrends T, van Cappellen P (2012) Oxygen dependency of neutorphilic $\mathrm{Fe}$ (III) oxidation by Leptothrix differs from abiotic reaction. Geomicrobiol J 29:550-560

51. Beveridge TJ, Murray RG (1980) Sites of metal deposition in the cell wall of Bacillus subtilis. J Bacteriol 141: 876-887.

52. Urrutia MM, Beveridge TJ (1994) Formation of fine-grained metal and silicate precipitates on a bacterial surface (Bacillus subtilis). Chem Geol 116: 261-280.

53. Sun J, Li Y, Liang X-J, Wangs PC (2011) Bacterial megnetosome: a nove biogenetic targeted drug carrier with potential multifunction. J Nanomater 2011: 1-13.

54. Nelson YM, Lion LW, Ghiorse WC, Shuler ML (1999) Production of biogenic Mn oxides by Leptothrix discophora SS-1 in a chemically defined growth medium and evaluation of their $\mathrm{Pb}$ adsorption characteristics. Appl Environ Microbio 65: 175-180.

55. Pourbaix M (1996) Atlas of electrochemical equilibria in aqueous solutions. Pergamon Press, Oxford, U. K. 
Citation: Kunoh T, Kunoh H, Takada J (2015) Perspectives on the Biogenesis of Iron Oxide Complexes Produced by Leptothrix, an Iron-oxidizing Bacterium and Promising Industrial Applications for their Functions. J Microb Biochem Technol 7: 419-426. doi:10.4172/1948-5948.1000249

56. Ferris FG, Schultze S, Witten TC, Fyfe WS, Beveridge TJ (1989) Metal interactions with microbial biofilms in acidic and neutral $\mathrm{pH}$ environments. App Environ Microbiol 55: 1249-1257.

57. Toner BM, Santelli CM, Marcus MA, Wirth R, Chan CS, et al. (2009) Biogenic iron oxyhydroxide formation at mid-ocean ridge hydrothermal vents: Juan de Fuca Ridge. Geochim Cosmochim Acta 73: 388-403.

58. Kunoh T, Hashimoto H, McFarlane IR, Hayashi N, Suzuki T, et al. (2015) Abiotic deposition of Fe complexes onto Leptothrix sheaths. SpringerPlus (submitted)

59. Tarascon J M, Aramand M (2001) Issues and challenges facing rechargeable lithium batteries. Nature 414: 359-367.

60. Hashimoto H, Kobayashi G, Sakuma R, Fujii T, Hayashi N, et al. (2014) Bacterial nanometric amorphous Fe-based oxide: a potential lithium-ion battery anode material. ACS Appl Mater Interfaces 6: 5374-5378.

61. Sakuma R, Hashimoto H, Kobayashi G, Fujii T, Nakanishi M, et al. (2015) High-rate performance of a bacterial iron-oxide electrode material for lithiumion battery. Mater Lett 139: 414-417.

62. Mandai K, Korenaga T, Ema T, Sakai T, Furutani M, et al. (2012) Biogenous iron oxide-immobilized palladium catalyst for the solvent-free Suzuki-Miyaura coupling reaction. Tetrahed Lett 53: 329-332.

63. Hashimoto H, Itadani A, Kudoh T, Kuroda Y, Seno M, et al. (2013) Acidic amorphous silica prepared from iron oxide of bacterial origin. ACS Appl Mater Interfaces 5: 518-523.

64. Hashimoto H, Itadani A, Kudoh T, Fukui S, Kuroda Y, et al. (2013) Nano- micrometer-architectural acidic silica prepared from iron oxide of Leptothrix ochracea origin. ACS Appl Mater Interfaces 5: 5194-5200.

65. Hashimoto H, Asaoka H, Nakano T, Kusano Y, Ishihara H, et al. (2012) Preparation, microstructue, and color tone of microtubule material composed of hematite/amorphous-silicate nanocomposite from iron oxide of bacterial origin. Dyes Pigments 95: 639-643.

66. Kusano Y, Fukuhara M, Takada J, Doi A, Ikeda Y, et al. (2010) Science in the art of the master Bizen potter. ACC Chem Res 43: 906-915.

67. Hashimoto H, Nakanishi M, Asaoka H, Maeda T, Kusano $\mathrm{Y}$, et al. (2014) Preparation of yellowish-red Al-substituted $-\mathrm{Fe}_{2} \mathrm{O}_{3}$ powders and their thermostability in color. ACS Appl Mater Interfaces 6: 20282-20289.

68. Horiishi N (2002) A historical survey of bengala in view of art and science. J Jap Soc Powder Powder Mettall 49: 1121-1127.

69. Hashimoto H, Fujii T, Nakanishi M, Kusano Y, Ikeda Y, et al. (2012) Synthesis and magnetic properties of magnetite-silicate nanocomposites derived from iron oxide of bacterial origin. Mater Chem Phys 136: 1156-1161.

70. Iwasaki K, Itoh T, Yamamura T (2005) Production conditions of acicular magnetic metal nanoparticles for magnetic recording. Mater Trans 46: 1368.

71. Ishihara H, Hashimoto H, Taketa E, Suzuki T, Mandai K, et al. (2014) Siliconrich, iron oxide microtubular sheath produced by an iron-oxidizing bacterium Leptothrix sp. strain OUMS1, in culture. Minerals 4: 565-577.

72. Suzuki $\mathrm{T}$, Hashimoto $\mathrm{H}$, Ishihara $\mathrm{H}$, Matsumoto $\mathrm{N}$, Kunoh $\mathrm{H}$, et al. (2012) Two types of morphologically distinct fibers comprising Gallionella ferruginea twisted stalks. Microb Environ 27: 338-341. 